\title{
Islamic Theology in European Universities
}

\section{Introduction}

The Muslim presence in Europe has a long and ambivalent history, which differs from country to country. Every European country has its own history of encounter with Islam that is shaped by its own context. That is why different models and traditions have developed within the European countries for interacting with Islam, which means that, given the various approaches and practices in individual countries, it is impossible to speak of a pan-European outlook.

Despite the different historically conditioned approaches of individual European countries to Islam, the developments in the 1960s and 1970s, when increased Muslim workers were recruited, showed similarities across borders. An oft-recurring assumption in the European context concerning the Muslim 'guest worker' is manifest in the expectation that the new arrivals would only be in Europe for a limited time and would then return to their home countries. Not only did the host countries - which recruited these people for economic reasons - think this would be the case, but the guest workers themselves, who had come for the same reasons, thought so as well.

That is why nothing much was done to integrate the new workers into society. The new workers were not expected to adjust to society, nor did the governments initiate the process of naturalisation. As would be emphasised later, it was a serious oversight, for things turned out quite differently than was first expected. The guest workers stayed longer and brought their families over from their native countries, which meant that, in distinction from their previous isolated lives, they were forced to some extent by the influx of their families to actively participate in public life. These developments revealed the omissions of the preceding years. It also became clear that the former guest workers and their family members had in the meantime become an integral part of society. But there were no models for integration that could correct the omissions and make the integration of the migrants into society easier.

The gradual change in the profile of the former guest workers, who had in the meantime become residents and whose children attended local schools, led to the first tentative steps towards integration. These initial considerations on integration first focused almost exclusively on learning German because inadequate knowledge of the language represented a major obstacle to communication that had in the meantime become unavoidable. The religious needs of Muslims, however, played no significant role, even though the debates on integration had greatly increased in the meantime. 
It had been obvious for a long time in the field of religion that the new citizens 'consumed' theological ideas that they brought with them from their home countries. The religious institutions founded by Muslims in Europe made do with transferring theological ideas from their countries of origin. These ideas were then further disseminated by imams in mosques that were organised along ethnic lines. The imams were educated outside of Europe in their mother tongue and had no knowledge of German. For a long time, no one was offended by the concomitant theological and personal dependence from abroad, which continues today, just as no one had been disturbed by the fact that 'guest workers' in Europe those first years lived as if they were still in their countries of origin.

The situation changed, however, through the changes in global politics and the growth of 'political Islam'. This had indeed been present for a long time in Europe but did not become active until the beginning of the $21^{\text {st }}$ century. The increase in politically motivated violence by Muslim fundamentalists, and recently in the West as well, additionally intensified the discussions around and concerning Islam in Europe. In this connection, the terrorist attacks on 9/11 in New York marked a decisive turning point in the encounter with Islam in the West.

It is regrettable that it was only after several religiously motivated attacks that it became clear that more was needed. In addition to learning the language, it was now accepted that, among other things, a reflective encounter with one's own religion was needed to be able to create the presuppositions for an Islamic theology that was in line with the new context. Nevertheless, adequate institutions needed for such a step were initially lacking, like the university, which would have made a critical reflection on Islam, i.e., on its own religion, possible.

With its social and public educational task, the university can provide such a space, as it had also done in connection with Christian denominations in the German context. As Reinhard Schulze emphasises:

It is not the case that only the interests of the Muslim communities are reflected on in the university, but it is also part of the claim of the university itself to be a place of academic interpretation of its society. If Muslims cultivate a Muslim discourse in our society, then it is also the task of the university to take up this discourse in such a way that it meets the academic condition of self-interpretation. (Schulze, 2012, 183)

Even if compensation for an oversight that lasted decades is probably no longer possible, the decision was made particularly in German-speaking areas to make the spiritual domestication of Muslims possible through the academic encounter with their religion in the European context. As a result of this initiative, some centres for Islamic theology were founded in Austrian and German universities that currently examine, among other things, the question of the principles of an Islamic theology with a European character (Aslan, 2012). Because the history 
of Islamic theology at European universities is still at an early stage of development, it is no easy task to establish certain principles. This is so, particularly given the fact that this is itself subject of theological study; it has to be defined and discussed only as the result of the process of establishing Islamic theology. As is the case with other established theologies at European universities, it can also be expected in Islamic theology that the answer to the question of the principles of this new Islamic theology will, however, vary according to the basic orientation of the individual centre and individual actors. This is certainly an advantage for the European context, which is stamped and characterised by plurality.

In spite of this open and still initial phase of finding an identity for Islamic theology at the European university, some principles should be discussed in this essay. In our view, these principles must be part of the Islamic self-interpretation at European universities if justice is to be done to the university character of Islamic theology. The considerations concerning this, however, are not to be understood as a closed conception but as suggestions for an emerging developmental process with the foundations and organisation of Islamic theology at the European universities.

Because it is impossible to present all relevant points of view, in this essay we will make do with discussing three aspects that play a central role in Islamic theology at European universities. They are indispensable for the development of new theological approaches and make it possible for Islamic theology to shape both Islamic and European discourse. We should clarify two important concerns already at the beginning that will facilitate access to this contribution. First, we will deliberately forego - with some exceptions - any discussion here of the problem of the scientific or academic status of theology in general and Islamic theology in particular because this discussion is not specific to Islam and would go beyond the scope of this essay. Second, we will briefly point out here that the term 'Islamic theology', which is not uncontested among Muslims, covers all current Islamic canonical disciplines that are concerned with the topic of God from their own respective perspectives. Because the context is essential for the revealing of the necessity and usefulness of further reflections, I will begin with discussing the context. 


\section{The European Context}

According to Joachim Willems, there is no 'pure' knowledge independent of context;

What we construct as an image of the world, i.e., of our natural environment and our fellow human beings as well of the values that in our view have greater or lesser validity, depends essentially on our cultural and religious backgrounds. It is not only the interpretation of experiences and perceptions that are accordingly cultural and religious - there are no 'pure' experiences and perceptions that are not influenced by culture and religion. (Willems, 2011, 65)

This means that context also plays an indispensable role regarding theological models. Given this, the question arises here as to what the characteristic elements of the current European context are from which Islamic theology with a European stamp should emerge. Two important elements stand out that characterise the European context in particular.

First, there is the principle of the secular democratic constitutional state as the most significant achievement of the Enlightenment and the modern period. This principle became widely established in Europe after a longer series of confrontations in the European context and constitutes the foundation of worldview and religious plurality in Europe. Thus, the secular democratic constitutional state is an important framework for all theological models that originate in the European context.

Viewed from the Muslim perspective, both the historical as well as actual developments in Islamic theology show that the encounter with secularism will be the greatest challenge to be overcome. This is much more of an issue for Islamic theology than established Christian theologies. The latter have been acquainted with this tradition for a long time and have experienced some conflicts themselves. In distinction from Christian theologies in Europe, the secular context, as we know it in Europe, is strange to Islam. The experiences Muslims have with secularism are based on the practices of their countries of origin, which are characterised by dictatorship, repression, and hostility to religion. This has led inevitably to a fundamentally hostile attitude to secularism that can also be seen in part in the present.

That is why the primary challenge consists in first developing a positive approach to a secular democratic constitutional state and to ground this theologically as well. The belief in the separation of religion and state has to be given priority. 
The state guarantees religion the status of legal person insofar as the religion guarantees a connection to actually acting individuals ... In a countermove, the religion recognises the legal competence of the state and limits the theological claim of validity to immediate matters of religion. (Schulze, 2010, 2)

Next is the recognition and acceptance of universal human rights as fundamental and universal, which brings us to another challenge that Islamic theology faces in the European context. The secular context is based on, among other things, the assumption of the inalienable dignity of the human being, on which other human rights and the fundamental attentiveness to anthropological questions can be based. Independent of other qualities of being human, here it is primarily a matter of humans being at the centre of these encounters. Such an attitude affects theology and concerns questions of both content and methodology.

From the perspective of content, the involvement of the aspects mentioned in Islamic theology would entail a paradigm shift in the direction of an 'anthropological turn' as a result of which the classical theological positions must be redefined. This means on the one hand an orientation to the subject in the sense of attentiveness to the individual and the social development of the person, her biography, and living conditions. On the other hand, it entails fundamental reflections on the foundation of human dignity in theological models. This is primarily a matter of the recognition of universal human rights as fundamental that are valid for all human beings. These rights should neither be limited nor denied, and that also excludes basing any attempts to do so on an appeal to religious sources. The consideration of human rights and the accompanying acceptance of plurality within and outside one's own religion is crucial for the future of the Islamic theology that emerges in the European context.

The secular context determines not only the relation between religion and the state and the equality of all people but also provides the framework for scientific and academic analyses at the university, which also arose in this context. That is why we will explore this aspect in the next section.

\section{Scientific Standards, Interdisciplinarity, and Renewal}

Next to the challenges already mentioned, like the separation of religion and state and respect for human rights, the scientific and academic context represents a particular challenge to Islamic theology just as it does to any theology. How great this challenge was in the past is indicated by Klaus von Stosch, who says in this connection: "The Enlightenment and the modern period have 
forced Christianity in Europe to rationalise its own faith to a considerable extent and to justify its faith in the forum of reason" (Von Stosch, 2012, 77). This is a process from which Islamic theology will and should not be spared if it wants to be part of the academic university landscape. Reinhard Schulze also underscores this when he says: "The Islamic self-interpretation that would qualify as academic is thus forced to enter into a discourse in which this accommodation to the secular conditions of the university is possible" (Schulze, 2012, 183).

The concrete challenges for Islamic theology in academia consist on the one hand in the encounter with scientific and academic standards regarding ways of thinking and working. On the other in going beyond self-preoccupation, Islamic theology is required to convey insights of academic theology with a view to the other sciences. Conversely, this also includes a deeper theological encounter with insights from other disciplines, such as the theory of evolution.

Altogether, the content of Islamic academic theology and forms of acquiring insight with a view to the European context are being put to the test. Islamic theology needs to abandon the notion that knowledge is closed and that acquiring knowledge is a static process. Rather, Islamic theology needs to establish new process-oriented forms that are open to historical circumstances. An Islamic theology that makes do with the perpetuation of old and familiar theological approaches can neither satisfy the academic requirement of an Islamic theology situated at the university nor develop new theological stimuli.

A renewal of Islamic theology does not necessarily imply disconnection from the rich tradition of Islamic theology or isolation from the current internal Islamic discourses as is often suggested. Rather, the complete opposite should happen: the current European context and the university location at a secular university should help Islamic theology connect with its earlier achievements. In the Middle Ages - and not just within Islam - these achievements were viewed as progressive and diverse. Aside from a few exceptions, current developments, especially outside the Western hemisphere, show that Islamic theology is far removed from its medieval achievements, it has instead drifted more and more towards an apologetic attitude and is thus no longer in a position to develop new approaches. Von Stosch also detects such a tendentially negative trend within present-day Islamic theology and argues that

[w]hile Islam in the Middle Ages had an excellent theology ... until now it has not sufficiently confronted the challenges of the Enlightenment and modernity. Therefore, until the present, only some initial approaches have developed for a modern Islamic theology. (Von Stosch, 2012, 78f.) 
Viewed in this way, the consideration of the present context, the observance of current academic standards, the openness to interdisciplinary work, and the constant examination of one's own results are not arbitrarily imposed instructions from outside, as they are often misunderstood to be, but standards that every theology has to follow if it wants to claim a place in an academic and scientific context in Europe. If we look it in this way, 'being true' to one's own tradition is not a matter of unquestioningly repeating old theological views that arose in a different context and therefore have little in common with the present. This loyalty, rather, is to be found in the constant renewal and adjustment to the environment and to the academic standards of the present.

How open the early Muslim scholars were to interdisciplinarity and how important the observance of academic standards was can be seen in the statements by the well-known Muslim philosopher and legal scholar Ibn Rushd (d. 1198 AD), known in Europe by the name Averroes. In his important discussion on the relation between philosophy or science and religion, he writes regarding the academic and scientific achievements of the Greek philosophers and scientists:

But if someone other than ourselves has already examined that subject, it is clear that we ought to seek help towards our goal from what has been said by such a predecessor on the subject, regardless of whether this other one shares our religion or not. (Ibn Rushd, 1961, 47)

The (Christian) history of theologies in Europe shows unambiguously that the way to theology that communicates and engages in comprehensible argumentation is possible only through its integration into the academic and scientific context. In connection with this, von Stosch writes, with a view to Christian theology:

Only because Christianity faced the challenges of such objections to faith by means of reason could it develop something like modern theology, which goes beyond the project of theology in antiquity and the Middle Ages in several respects. (Von Stosch, 2012, 78)

\section{Interreligious Collaboration: A Theology for All}

In a religiously pluralist society like Europe, interreligious collaboration has enormous significance for the reception and cultivation of the peaceful and respectful co-existence of different cultures and religions. In addition to the numerous other possibilities of engaging in dialogue, the embedding of Islamic theology in the university setting is a unique and challenging opportunity - together with Christian theologies - to deepen interreligious collaboration on the 
theological level and to develop theological foundations for a mutual exchange. Von Stosch is not exaggerating when he says that the "multireligious society in Europe ... [can] succeed only if 'challenge theology' is accepted by Muslim and Christians both" (ibid., 79).

The necessity of working together and the cross-fertilisation between the various theologies, especially between the monotheistic ones, arise not only from the common origin of these religions from their identical "epistemic presuppositions" (Schulze, 2010, 5). They are also strongly conditioned by the present challenges that they can only meet together. In a time that is characterised on the one hand by a constantly diminishing sensitivity to religion and on the other by an increase in religiously motivated violence, no special arguments are needed to underscore the necessity for close co-operation in the interreligious area.

The classical Muslim scholars recognised Islam's theological interdependence with Jewish and Christian theology quite early and made use of it. They resorted time and again to the sources of both religions in order to close the gaps in their own knowledge. Nevertheless, this tradition has also been extensively weakened because of various, primarily political, reasons in Muslim-majority countries and has fallen into disrepute. This has led to interreligious dialogue and cross-fertilisation on the theological level occurring more in secular Western contexts, which once again makes clear the uniqueness of our European context. The quality of collaboration between established theologies - here the Islamic and Christian - at European universities will decisively influence not only the future of Islamic theology but also that of theology in general.

\section{Conclusion}

As already stated several times, the establishment of Islamic theology at European universities is a great opportunity for the renewal of Islamic theology in the free and autonomous space of the university and to provide new theological approaches. Unfortunately, these conditions are not present everywhere, especially not in those countries where the majority of Muslims live.

Islamic theology - especially in Muslim-majority countries - appears to have long ago lost its vitality and its relation to reality. Even so, however the rich theological tradition of Islam in the Middle Ages, as well as some personalities in the present, and the founding of Islamic theological centres in Europe provide hope for new approaches in Islamic theology that conforms to both tradition and the new context. Von Stosch also comes to the conclusion 
that Islam in Europe is confronted at present with the challenge to develop a modern theology in accordance with Western academic standards, and ... that there are promising approaches to this that could also be fruitful for Christian theology. (Von Stosch, 2012, 79)

The establishment of Islamic theology at European universities is a long process with many different challenges. Despite that, however, the recent developments in Islamic theology justify the hope that the desired new approaches in Islamic theology will come out of Europe. 
